\title{
Turbidimetric Assay of Apolipoprotein A-II
}

\author{
By H. Schriewer, F. Emke, G. Assmann
}

Institut für Klinische Chemie und Laboratoriumsmedizin (Zentrallaboratorium) der Medizinischen Einrichtungen der Westfälischen Wilhelms-Universität Münster

(Received October 19, 1984/February 11, 1985)

Summary: A turbidimetric assay for the quantification of apolipoprotein A-II in serum is described. Its adaptation for the Cobas Bio Analyser (Hoffmann La Roche) is reported.

Regression analysis of apolipoprotein A-II values measured by turbidimetry revealed a good measure of agreement with the data obtained by radial immunodiffusion (RID) $(\mathrm{r}=0.90, \mathrm{y}=0.97 \mathrm{x}+0.021, \mathrm{n}=$ $100)$ as well as with data obtained by immunonephelometry $(r=0.838, y=0.925 x+0.029, n=34)$. A variation coefficient of $3.2 \%(n=18)$ was found in relation to the precision in the series and a variation coefficient of $3.5 \%(n=36)$ in relation to day to day precision.

\section{Turbidimetrische Bestimmung von Apolipoprotein A-II}

Zusammenfassung: Es wird ein turbidimetrisches Verfahren zur Bestimmung von Apolipoprotein A-II im Serum beschrieben, das an den Analysator Cobas Bio (Hoffmann La Roche) adaptiert wurde.

Die Regressionsanalyse der mittels Turbidimetrie ermittelten Apolipoprotein A-II-Werte ergab eine gute Übereinstimmung mit Apolipoprotein A-II-Werten, die mittels radialer Immundiffusion (RID) $(r=0,90$, $\mathrm{y}=0,97 \mathrm{x}+0,021, \mathrm{n}=100) \mathrm{bzw}$. mittels Immunnephelometrie bestimmt wurden $(\mathrm{r}=0,838, \mathrm{y}=0,925 \mathrm{x}+$ $0,029, n=34)$. Der Variationskoeffizient in der Serie betrug 3,2\% $(n=18)$ und der Variationskoeffizient von Tag zu Tag 3,5\% $(\mathrm{n}=36)$.

\section{Introduction}

Epidemiological $(1-5)$ and clinical $(6,7)$ studies in recent years have shown that HDL cholesterol is an indicator of coronary heart disease. The possible relation of further $\mathrm{HDL}$ components (HDL phospholipids, HDL apolipoprotein A-I, HDL àpolipoprotein A-II) to the risk of coronary heart disease, however, is until now unknown. This may be due to the fact that the analysis of phospholipids and apolipoproteins is more laborious than the analysis of cholesterol.

Among the different methods used for the routine analysis of apolipoprotein A-I immunonephelometry may be the method of choice $(8-11)$. For the determination of apolipoprotein A-II numerous methods - radioimmunoassay $(12,13)$, radial immunodiffusion (RID) (14), enzyme immuno assay (15) and immunonephelometry $(16,17)$ - have been described. However, most of these methods are laborious and not suitable for processing the large number of samples required for epidemiological studies.

In the present study we report the development of a turbidimetric end point assay for the determination of apolipoprotein A-II using the Cobas Bio Centrifugal Analyser (Hoffmann La Roche). 


\section{Materials and Methods}

Sample material

We used samples of the serum collected for the "Prospective epidemiological study in company employees in Westfalia" reported elsewhere (18).

Antibodies

As apolipoprotein A-II antibody, we used the commercial antibody from rabbits Anti A-II Immuno, order No. 4833005, Immuno Co., D-6900 Heidelberg, FRG. In two dimensional immunoelectrophoresis the antibody was monospecific for apolipoprotein A-II, using isolated LDL $(1.006-1.040 \mathrm{~kg} / \mathrm{l} \mathrm{UZ}$ serum fraction) and isolated apolipoproteins (apolipoprotein A-I, A-II, C-I, C-II, C-III, B) as antigens.

\section{Turbidimetry}

The turbidimetric assay of apolipoprotein A-II was performed using the Cobas Bio Analyser (Hoffmann La Roche). The reagent contained:

- $300 \mu$ l antibody solution, diluted 1:15 with a phosphate buffered polyethylenglycol solution (Beckman Immunochemical System)

- $20 \mu$ diluted sample (dilution 1:150 with detergent, Immuno Co., D-6900 Heidelberg, FRG, order no. 4998005)

$-10 \mu \mathrm{H}_{2} \mathrm{O}$

After an incubation period of 60 minutes at $25^{\circ} \mathrm{C}$ changes in turbidity were recorded. For calibration the standard (immunoneph Reference Standard Apoproteins human Immuno Co., D-6900 Heidelberg, FRG, order No. 4380105) was diluted $1: 100,1: 150,1: 200,1: 250,1: 300$ and $1: 400$ with the detergent.

The parameter list for the Cobas Bio was as follows:

1 units

2 calculation factor

3 standard 1 conc

3 standard 2 conc

3 standard 3 conc

3 standard 4 conc

3 standard 5 conc

3 standard 6 conc

6 limit

7 temperature $\left({ }^{\circ} \mathrm{C}\right)$

8 type of analysis

9 wavelength (nm)

10 sample volume $(\mu \mathrm{l})$

11 diluent volume $(\mu \mathrm{l})$

12 reagent volume $(\mu \mathrm{l})$

13 incubation time (s)

14 start reagent volume $(\mu \mathrm{l})$

15 time of first reading (s)

16 time interval (s)

17 number of readings

18 blanking mode

19 printout mode

$$
\begin{aligned}
& 8 \\
& 1000 \\
& 0.2479(1: 400) \\
& 0.3305(1: 300) \\
& 0.3966(1: 250) \\
& 0.4958(1: 200) \\
& 0.6610(1: 150) \\
& 0.9901(1: 100) \\
& 0 \\
& 25.0 \\
& 7.5 \\
& 340 \\
& 20 \\
& 10 \\
& 300 \\
& 0 \\
& 0 \\
& 10.0 \\
& 300 \\
& 12 \leqq 60 \mathrm{~min} \\
& 1
\end{aligned}
$$

\section{Immunonephelometry}

The immunonephelometric assay was performed as end point immunonephelometry using a Beckmann ICS system as described by Rosseneu et al. (17).

\section{Precipitation of apolipoprotein B-containing lipoproteins}

The precipitation of apolipoprotein B-containing lipoproteins was performed using phosphotungstic acid/ $\mathrm{MgCl}_{2}$ (Boehringer Mannheim, order No. 400971) as described elsewhere (19).

\section{Apolipoprotein A-II determination by RID}

The apolipoprotein A-II determination by RID was performed according to Mancini et al. (20). Antibody solution (400 $\mu \mathrm{l})$ was mixed with $20 \mathrm{ml} 10 \mathrm{~g} / \mathrm{l}$ agarose solution containing Trisbarbital-lactate buffer pH $8.6(0.045 \mathrm{mmol} / 1 \mathrm{Tris}, 0.015 \mathrm{~mol} / \mathrm{l}$ barbituric acid, $1.9 \mathrm{mmol} / 1 \mathrm{Na}$ azide, $0.21 \mathrm{mmol} / 1 \mathrm{Ca}$-lactate. The sample volume was $5 \mu$ l (diluted 1:50 in $0.15 \mathrm{~mol} / 1 \mathrm{NaCl}$ ). As standard we used the standard R.LD Reference Standard Apoproteins human order No. 4910005, Immuno Co., D-6900 Heidelberg, FRG, diluted $1: 25,1: 50$ and $1: 100$ in $0.15 \mathrm{~mol} / \mathrm{l}$ $\mathrm{NaCl}$. The incubation time was 5 days at room temperature. The ring diameters were measured after staining with Coomassie Blue R (Serva, D-6900 Heidelberg, FRG).

\section{Results}

\section{Turbidimetric reaction}

The kinetics of the alterations of the turbidimetric light absorption measured at different concentrations of apolipoprotein A-II are shown in figure 1. The end point of the reaction was attained after 60 minutes.

\section{Linearity of turbidimetry}

We studied the linearity of the apolipoprotein A-II determination measured by turbidimetry using a series of fresh pool serum dilutions. The measured values were proportional to the sample dilutions within the tested range $(0.24 \mathrm{~g} / \mathrm{l}-0.66 \mathrm{~g} / \mathrm{l})$ (fig. 2).

\section{Precision of turbidimetry}

The coefficient of variation for the precision in the series was $3.2 \%(\overline{\mathrm{x}} \pm$ S.D.: $0.356 \pm 0.011 \mathrm{~g} / \mathrm{l}, \mathrm{n} \equiv$ 18). Day to day precision was determined with serum samples taken from the fresh serum pool and stored in aliquots at $-70^{\circ} \mathrm{C}$. The coefficient of variation for day to day precision was $3.5 \%(\overline{\mathrm{x}} \pm$ S.D.: 0.333 $\pm 0.015 \mathrm{~g} / \mathrm{l}, \mathrm{n}=36$ ).

Apolipoprotein A-II measured by turbidimetry in the supernatant after precipitation of apolipoprotein $B$ containing lipoproteins with phosphotungstic acid/ $M g C l_{2}$

Comparison of apolipoprotein A-II data measured in native serum $(x)$ and measured in the supernatant after precipitation of apolipoprotein B-containing lipoproteins with phosphotungstic acid/ $\mathrm{MgCl}_{2}$ (y) resulted in a good correlation of the obtained values $(r=0.91, y=0.88 x+0.047, n=30)$ (fig. 3). The mean values measured in native serum $(x=0.390$ $. \mathrm{g} / \mathrm{l})$ and measured in the polyvinylsulphate supernatant $(\mathrm{x}=0.392 \mathrm{~g} / \mathrm{l})$ : were almost identical. 


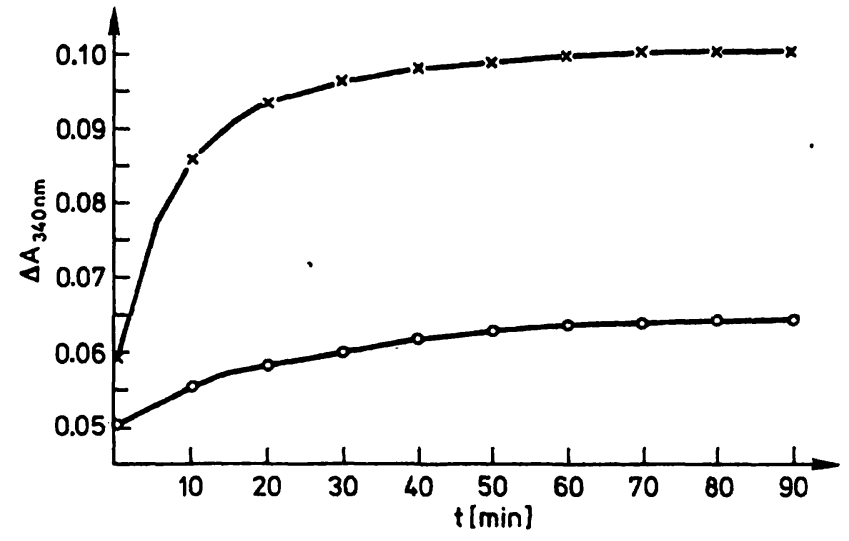

Comparison of turbidimetry and immunonephelometry

The immunonephelometric assay and the turbidimetric measurement of apolipoprotein A-II gave nearly identical values $(r=0.838, y=0.925 x+$ $0.029, \mathrm{n}=34$ ) (fig. 4).

\section{Comparison of turbidimetry and RID}

Regression analysis of the data obtained by turbidimetry ( $\mathrm{y}$ ) and by RID ( $\mathrm{x}$ ) indicated that apolipoprotein A-II values in normotriglyceridaemic sera

Fig. 1. Course of reaction of apolipoprotein A-II. $\mathrm{x} \longrightarrow \mathrm{x}$ Serum 1: $0.66 \mathrm{~g} / \mathrm{l}$ apolipoprotein A-II $\Delta_{340 \mathrm{~nm}}$ $\max =0,098$

O- $\bigcirc$ Serum 2: $0.24 \mathrm{~g} / \mathrm{l}$ apolipoprotein A-II $\Delta_{340 \mathrm{~nm}}$ $\max =0.065$

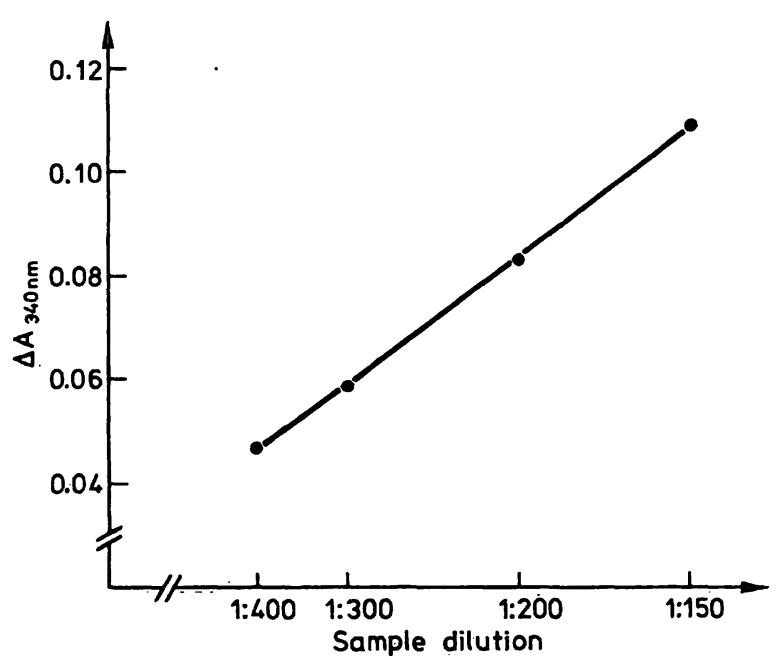

Fig. 2. Measured apolipoprotein A-II values as a function of the amount of sample used.

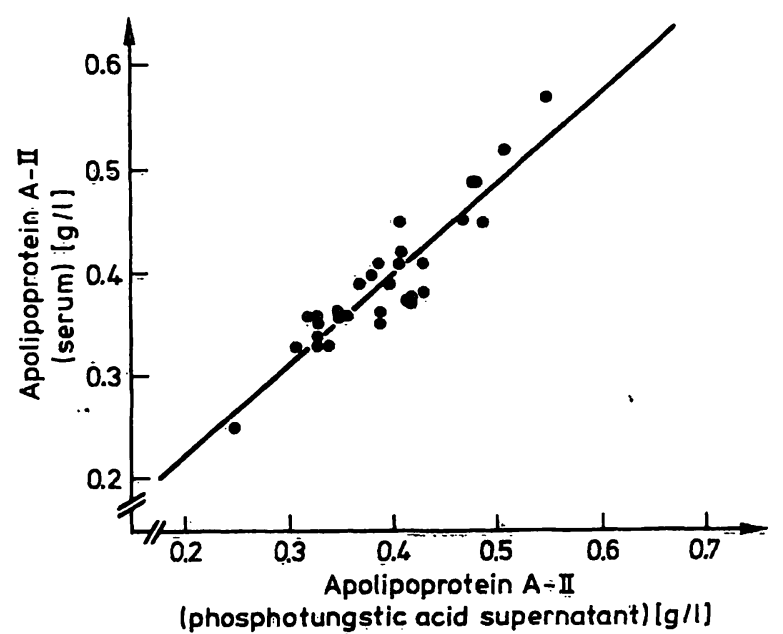

Fig. 3. Regression analysis of apolipoprotein A-II measured in the supernatant after precipitation of apolipoprotein B-containing lipoproteins with phosphotungstic acid/ $\mathrm{MgCl}_{2}$ (x) and measured in the total serum (y): $\mathrm{r}=$ $0.91, \mathrm{y}=0.88 \mathrm{x}+0.047, \mathrm{n}=30$.

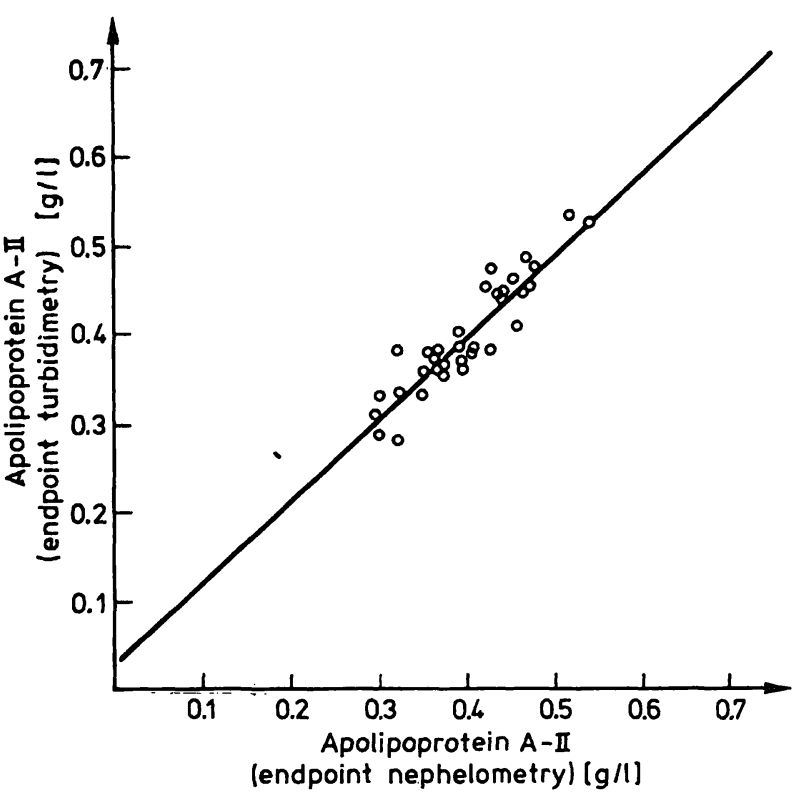

Fig. 4. Regression analysis of apolipoprotein A-II measured by end point nephelometry $(x)$ and measured by turbidimetry $(\mathrm{y}) \cdot \mathrm{r}=0.838, \mathrm{y}=0.925 \mathrm{x}+0.029, \mathrm{n}=$ 34.

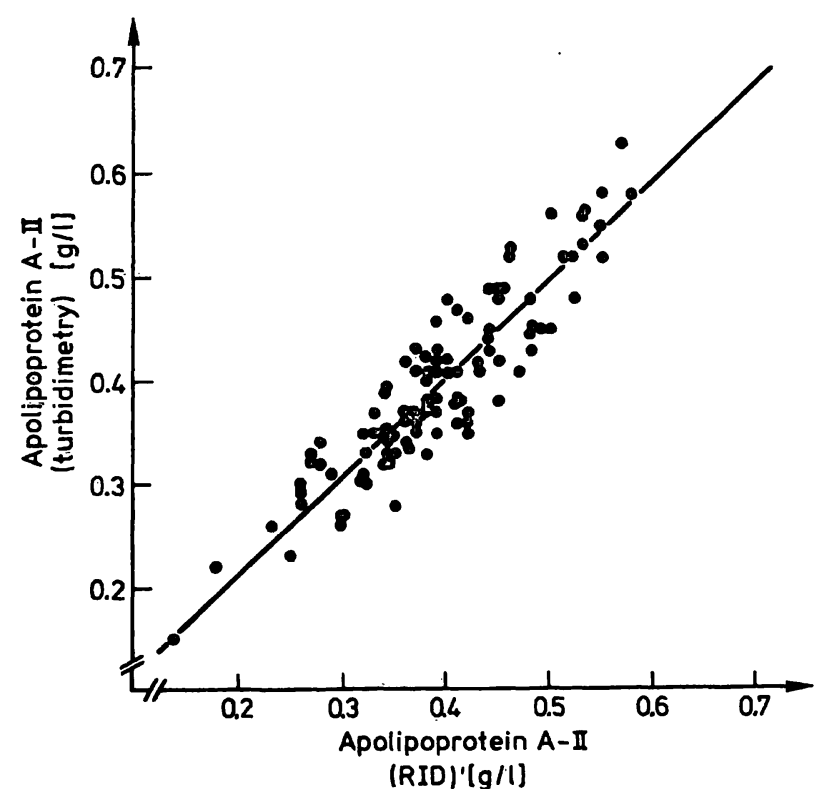

Fig. 5. Regression analysis of apolipoprotein A-II measured by RID ( $x$ ) and measured by turbidimetry ( $y)$ in normolipidaemic sera (triglycerides $<2.28 \mathrm{mmol} / \mathrm{l}$ ). $\mathrm{r}=$ $0.90, \mathrm{y}=0.97 \mathrm{x}+0.021, \mathrm{n}=100$ ). 
(triglycerides $<2.28 \mathrm{mmol} / \mathrm{l}$ ) analysed by both methods corresponded well $(\mathrm{r}=0.90, \mathrm{y}=0.97 \mathrm{x}+$ $0.021, \mathrm{n}=100$ ) (fig. 5). The mean values measured by both methods (turbidimetry $\overline{\mathrm{x}}=0.395 \mathrm{~g} / \mathrm{l}, \mathrm{RID}$ $\overline{\mathrm{x}}=0.389 \mathrm{~g} / \mathrm{l}$ ) were nearly identical. A similar correspondence of results was found for hypertriglyceridaemic sera (triglycerides $>2.28 \mathrm{mmol} / \mathrm{l}$ $<6.84 \mathrm{mmol} / \mathrm{l})(\mathrm{r}=0.97, \mathrm{y}=0.97 \mathrm{x}+0.030, \mathrm{n}=$ 21).

\section{Sample stability}

Sample stability was tested by analysing fresh samples and aliquots of samples which had been stored for 11 months at $-20^{\circ} \mathrm{C}$. There was no significant difference in values obtained from fresh samples $(0.273 \mathrm{~g} / \mathrm{l})$ and from samples stored at $-20^{\circ} \mathrm{C}(0.275 \mathrm{~g} / \mathrm{l})$ (mean of double determinations).

\section{Discussion}

High density lipoproteins are a heterogenous group of macromolecules with different composition and different physicochemical properties $\left(\mathrm{HDL}_{1}, \mathrm{HDL}_{2}\right.$, $\mathrm{HDL}_{3}$ ). For the quantification of $\mathrm{HDL}$ it is useful to measure HDL cholesterol as well as HDL apolipoproteins. However, a substantial problem for the quantification of apolipoproteins, especially of apolipoprotein A-II, may be the fact that several antigenic sites of apolipoprotein A-II are masked by its protein-protein and protein-lipid interaction within HDL (12). An exposure of the antigenic sites may be possible by organic solvent extraction of plasma (16) or by incubation of HDL with guanidine hydrochloride (12). Recently an immunonephelometric method for quantification of apolipoprotein A-II in plasma has been developed using sodium cholate for the exposition of its antigenic sites (17). Since our data from turbidimetry are in good agreement with the data from the immunonephelometric method, it can be supposed that the detergent used in our assay will equally expose

\section{References}

1. Miller, G. J. \& Miller, N. E. (1975) Lancet $I, 16-19$.

2. Rhoads, G. G., Gulbrandsen, C. L. \& Kagan, A. (1976) New Engl. J. Med. 294, 293-298.

3. Berg, K., Borresen, A. \& Dahlen, G. (1976) Lancet I, $499-502$.

4. Castelli, W. P., Doyle, J. T., Gordon, T., Hames, C. G., Hjortland, M. C., Hulley, S. B., Kagan, A. \& Žukel, W. J. (1977) Circulation 55, 767-772.

5. Gordon, T., Castelli, W. P., Hjortland, M. C., Kannel, W. B. \& Dawber, T. R. (1977) Ann Int. Med. 87, 393-397.

6. Barboriak, J. J., Anderson, A. J., Rimm, A. A. \& King, J. F. (1979) Metabolism 28, 735-738. the antigenic sites of apolipoprotein A-II without essentially affecting the antigen-antibody reaction. This supposition is supported by the good agreement between the data for apolipoprotein A-II obtained by RID and by turbidimetry, as well as the close agreement between the values for apolipoprotein AII data measured by turbidimetry' in total serum and in the apolipoprotein B free supernatant.

A substantial problem in the immunochemical quantification of apolipoproteins is the application of a suitable standard. Since previous studies have shown that immuno-complexes with isolated A-II resulted in lower light scattering by immunonephelometry than complexes with delipidated HDL (16), isolated apolipoprotein A-II may not be suitable as a primary standard. Therefore, isolated $\mathrm{HDL}_{3}$ may be preferred as a secondary standard for the standardisation of apolipoprotein A-II. In the present study a commercial apolipoprotein A-II standard was used which behaved similarly to the serum sample after treatment with detergent. However, the lyophilised standard used for RID was not suitable for turbidimetric apolipoprotein A-II assay because incubation of the standard with the detergent resulted in an enhancement of turbidimetry in comparison with the serum samples.

A great advantage of the turbidimetric measurement of apolipoprotein A-II is the high precision of this method. The intra- and interassay CV were only half of those reported for the immunonephelometric method (17). Another advantage of our described method may be the relatively low reagent volume used and the relatively high velocity of the determination in comparison with other described immunochemical methods $(16,17)$.

\section{Acknowledgement}

We thank Mr. B. Tambyrajah and Mr. M. Sandkamp for their technical assistance.
7. Kladetzky, R. G., Assmann, G., Walgenbach, S., Tauchert, P. \& Helb, H.-D. (1980) Artery 7, 191-205.

8. Rosseneu, M., Vercaemst, R., Vinaimont, N., Van Tarnout, P., Henderson, L. O. \& Herbert, P. N. (1981) Clin. Chem. $27,856=859$.

9. Funke, H. \& Assmann, G. (1982) .C̈lin. Chem. 28, $1153-1158$.

10. Steinberg, K. K., Cooper, G. R., Graiser, S. R. \& Rosseneu, M. (1983) Clin. Chern. 29, 415-426.

11. Heuck, C.-Ch., Erbe, I. \& Flint-Hansen, P. (1983) Clin. Chem. 29, 120-125. 
12. Musliner, Th. A., Garner, P. A., Henderson, L. O. \& Herbert, P. N. (1982) Arteriosclerosis 2, 160-169.

13. Assmann, G., Smootz, E., Alder, K., Capurso, A. \& Oette, E. (1977) J. Clin. Invest. 59, 565-575.

14. Borresen, A.-L. \& Berg, K. (1980) Artery 7, 139-160.

15. Dufaux, B., Ilsemann, K. \& Assmann, G. (1983) J. Clin. Chem. Clin. Biochem. 21, 39-43.

16. Heuck, C.-Ch., Erbe, I., Frech, K., Lohse, P. \& Münscher, M. (1983) Clin. Chem. 29, 1385-1388.
17. Rossenau, M., Vinaimont, N., Musliner, T. A., Bernier, D., Herbert, P. N. \& Belpaire, R. (1984) Clin. Chem. 30, 234-237.

18. Assmann, G., Oberwittler, W., Schulte, H., Schriewer, H., Funke, H., Epping, P. H. \& Hauss, W. H. (1980) Internist $21,446-459$.

19. Assmann, G., Schriewer, H., Schmitz, G. \& Hägele, E.-O. (1983) Clin. Chem. 29, 2026-2030.

20. Mancini, G., Carbonara, A. O. \& Heremans, J. F. (1965) Int. J. Immunochem. 2, 235-254.

Professor Dr. H. Schriewer Institut für Klinische Chemie und Laboratoriumsmedizin Medizinische Einrichtungen der Universität Münster Albert-Schweitzer-Straße 33 D-4400 Münster 
